\title{
Research Article \\ Effect of system rice intensification on root characteristics and dry matter production of rice
}

\author{
K. RAJENDRAN AND V. GANESA RAJA
}

\section{SUMMARY}

Field experiments were carried out during Rabi seasons of 2007-08 and 2008-09, to evaluate the crop establishment techniques and weed management practices under system of rice intensification. The experiments were laid out in Split Plot Design with three replications with main plot consisted of three levels age of seedlings viz., 14, 18 and 22 days old seedlings were evaluated with two levels of planting methods viz., SRI planting and mechanical planting. Four levels of weed management practices viz., hand weeding two times at 25 and 45 DAT, mechanical weeding three times at 10, 25 and 45 DAT, pre-emergence application of butachlor @ $1.25 \mathrm{~kg}$ a.i. ha ${ }^{-1}+$ two mechanical weeding at 25 and 45 DAT and unweeded check were assigned to sub plot. Transplanting of 14 days old seedlings with manual planting and Pre emergence application of butachlor @ $1.25 \mathrm{~kg} a . i$ ha $^{-1}+$ two mechanical weeding at 25 and 45 DAT had significantly higher root characteristics viz., root length, root volume, root dry weight and more crop dry matter production.

Key Words : SRI, Root length, Root volume, Root dry weight, DMP

How to cite this article : Rajendran, K. and Raja, V. Ganesa (2016). Effect of system rice intensification on root characteristics and dry matter production of rice. Internat. J. Plant Sci., 11 (1): 28-32.

Article chronicle : Received : 24.06.2015; Revised : 05.11.2015; Accepted : 19.11.2015

\author{
$\longrightarrow$ MEMBERS OF THE RESEARCH FORUM • \\ Author to be contacted : \\ K. RAJENDRAN, Central Institute for Cotton Research, Regional Station, \\ COIMBATORE (T.N.) INDIA \\ Email: kr_agro@ rediffmail.com
}

Address of the Co-authors:

V. GANESA RAJA, Department of Agronomy, Agricultural College and

Research Institute, MADURAI (T.N.) INDIA 